\title{
Quality of Plain Set Yoghurt as affected by Levels of Ultrafiltration Concentration of Milk and Inoculum of Yoghurt Culture
}

\author{
Narayana Mudiyanselage Nayana Kumari Narayana ${ }^{1 *}$, Vijay Kumar Gupta ${ }^{2}$
}

${ }^{l}$ Department of Animal Science, Faculty of Agriculture, University of Ruhuna, Mapalana, Kamburupitiya, Sri Lanka ${ }^{2}$ Division of Dairy Technology, National Dairy Research Institute, Karnal, Haryana, India

\section{A R T I C L E I N F O}

Article history:

Received 18 February 2016

Accepted 25 April 2016

Available online, ISSN: 2148-127X

Keywords:

Ultrafiltration

Inoculum level

Spontaneous whey syneresis

Water holding capacity

Textural attributes

Corresponding Author:

E-mail: nayananarayana1970@gmail.com

\begin{abstract}
A B S T R A C T
Quality of plain set yoghurt was investigated by varying levels of ultrafiltration concentration of cow skim milk (1-without ultrafiltration, 1.5 and 2 folds) and inoculum (2, 2.5 and 3\%) of yoghurt culture (Lactobacillus delbrueckii subsp. bulgaricus and Streptococcus thermophilus $1: 1$ ). Titratable acidity development and $\mathrm{pH}$ reduction were significantly faster during incubation of yoghurt with increasing ultrafiltration concentration level and inoculum level. Increased ultrafiltration concentration level decreased spontaneous whey syneresis, but increased water holding capacity and firmness of the product significantly. Body \& texture and overall acceptability scores were significantly better in yoghurts prepared from 1.5 fold concentrated milk irrespective of the inoculum level studied. Inoculum level did not show any significant effect on the quality of yoghurt, but higher inoculum level decreased the incubation period significantly. Optimized product was obtained with 1.5 fold concentrated skim milk standardized to $3.3 \%$ fat and incubated with $2 \%$ inoculum level in about five and a half hour of incubation. Optimized product had $13.60 \pm 0.02 \%$ total solids, $3.31 \pm 0.01 \%$ fat, $5.27 \pm 0.04 \%$ protein, $4.20 \pm 0.03 \%$ lactose and $0.82 \pm 0.02 \%$ ash. Whey syneresis, water holding capacity and firmness in optimized product were nil, $63.49 \%$ and $1.89 \mathrm{~N}$, respectively. Thus, high quality plain yoghurt could be prepared by employing ultrafiltration, without addition of stabilizers, which is otherwise widely used commercially for the manufacture of yoghurt to control its wheying off and body.
\end{abstract}

\section{Introduction}

Yoghurt is a popular fermented dairy product produced by bacterial fermentation of milk. Global yoghurt market expands rapidly over the years due to the growing consumer demand for convenient and health promoting products. TechNavio's analysts forecast that the global yogurt market is growing at a Compound Annual Growth Rate (CAGR) of $6.72 \%$ over the period from 2013-2018 (Anon, 2014). Among the different forms of yoghurt, set yoghurt is very popular in some countries of the world. Set yoghurt is produced by packaging the yoghurt mix into individual containers before fermentation.

Quality and consumer satisfaction are vital for the popularization of any product including set yoghurt. Set yoghurt should have a curd with sufficient hardness to stand up to the impact caused by shaking during transportation (Horiuchi et al., 2009). Whey Syneresis is a major defect of set-style yoghurt (Lucey, 2001). Factors influencing yoghurt texture and whey syneresis include total solids (TS) content, milk composition, homogenization, type of culture, acidity resulting from growth of bacterial cultures and heat treatment of milk (Harwalkar and Kalab, 1986).
Increasing the TS content in the milk base increases visco-elastic properties and water holding capacity (WHC) of yoghurt proportionately (Sodini et al., 2004), which leads to reduced whey syneresis. The nature and relative proportions of the different proteins in the dry matter of a yoghurt mix have a significant impact on the texture of the final product (Modler et al., 1983). Ultrafiltration (UF) is a technique which selectively concentrates milk in favour of proteins. Hence, it can be used to manufacture various cultured dairy products including set yoghurt. Even though, UF offers several benefits to yoghurt formulations, increase in protein and mineral content give rise to an increase in the buffering capacity of the retentates (Mistry and Kosikowski, 1985; El-Gazzar and Marth, 1991; Salaun et al., 2005) hence, slows down the fermentation of yoghurt mix or even hinder that the target $\mathrm{pH}$ of the final product is reached (El-Gazzar and Marth, 1991). Mistry and Kosikowski (1985) reported that, high buffering capacity places more demands on the starter culture to produce more lactic acid (LA) for the reduction of $\mathrm{pH}$ during fermentation of yoghurt. In general, starter bacteria growth is influenced by many factors such as chemical composition of milk 
base, the amount of inoculum, milk temperature, incubation time and cooling time of the milk (Mahdian and Tehrani, 2007). No studies have been reported in the literature to investigate the effect of inoculum level of yoghurt culture on physico-chemical, textural and sensory characteristics of plain set yoghurt made employing ultrafiltered milk. Therefore, present investigation was undertaken to see the effect of UF concentration level (UFCL) of cow skim milk and inoculum level (IL) of yoghurt culture on physico-chemical, textural and sensory characteristics of plain set yoghurt.

\section{Materials and Methods}

\section{Materials}

Raw cow skim milk and cream (about 50-55\% fat) was obtained from Experimental Dairy of National Dairy Research Institute, Karnal, Haryana, India. Well reputed brand of commercial yoghurt containing Streptococcus thermophilus and Lactobacillus delbrueckii subsp. bulgaricus was used as the starter culture for the production of yoghurt. All the chemicals used were of analytical grade.

\section{Yoghurt}

Ultrafiltration of Cow Skim Milk and Production of

Cow skim milk was heated to $80^{\circ} \mathrm{C}$ without holding, cooled to $55-60^{\circ} \mathrm{C}$ and transferred to the balance tank of pilot UF plant $\{$ Tech-Sep, France with tubular module (channel diameter, $6 \mathrm{~mm}$ ) having $\mathrm{ZrO}_{2}$ membrane (membrane surface area, $1.68 \mathrm{~m}^{2}$ and membrane molecular weight cut off, 50,000 Dalton) $\}$ and ultrafiltered at $50-55^{\circ} \mathrm{C}$ to 1.5 and 2 fold UFCL s. Cow skim milk and UF cow skim milk retentates were standardized to $3.3 \%$ fat by adding calculated amount of cow milk cream. Resultant standardized milks were preheated to $65-70^{\circ} \mathrm{C}$; homogenized in a two-stage homogenizer (M/s Goma Engineers, Mumbai) at 140 and $35 \mathrm{~kg} / \mathrm{cm}^{2}$ at $1^{\text {st }}$ and $2^{\text {nd }}$ stages, respectively; heat treated at $85^{\circ} \mathrm{C} / 30 \mathrm{~min}$ in a thermostatically controlled water bath (NAVYUG, India); cooled immediately in an ice water tub to $42-45^{\circ} \mathrm{C}$; inoculated with varying quantities $(2,2.5$ and $3 \%$ ) of activated (in $12 \%$ sterilized reconstituted skim milk) yoghurt culture; mixed; filled in clean polystyrene cups; covered with lids and incubated at $42 \pm 1^{\circ} \mathrm{C}$ until about $0.8 \%$ LA was developed. Yoghurts were then immediately transferred to a refrigerator maintained at $4 \pm 1^{\circ} \mathrm{C}$.

\section{Physicochemical Analysis}

A pH meter (PHAN LABINDIA Model, Labtek Eng. Pvt. Ltd. India) was used to determine $\mathrm{pH}$ of yoghurt during incubation. Titratable acidity (TA) during incubation of yoghurt, fat content of skim milk and UF cow skim milk retentates were determined as per the methods given in BIS (1981a). Fat content in cream and yoghurts were determined as per the methods given in BIS (1977) and in BIS (1981b), respectively. Protein content of yoghurt was determined by semi micro Kjeldhal method (Menefee and Overman, 1940). Lactose content in yoghurt was determined by Lane-Enyon method described in BIS (1981b). Ash content in yoghurts was determined as per the method given in BIS (1981b). Total solids of yoghurts were determined according to Anon (2005).

\section{Spontaneous Whey Syneresis (SWS)}

Siphon method described by Amatayakul et al. (2006) was used with slight modifications (Narayana and Gupta, 2013) to determine the SWS of yoghurt. A cup of yoghurt $(100 \mathrm{ml})$ was tilted immediately after removing from the refrigerator at an angle of $45^{\circ}$ to collect the surface whey. The collected whey was siphoned out with a graduated syringe to which a needle was attached. The siphoning was performed within $10 \mathrm{~s}$ to avoid forced leakage of whey from the yoghurt. The volume of siphoned whey was directly expressed as the percentage of spontaneous whey syneresis.

\section{Water Holding Capacity}

The WHC was measured by a centrifugation method given by Supavititpatana et al. (2009). Within $12 \mathrm{~h}$ of the production of yogurt, a $10 \mathrm{~g}$ sample was centrifuged at $2,000 \mathrm{~g}$ for $60 \mathrm{~min}$ at $10 \pm 1^{\circ} \mathrm{C}$. The supernatant was removed within less than $10 \mathrm{~s}$ and the wet weight of the pellet was recorded. The WHC was expressed as follows.

$$
\text { WHC }(\%)=\frac{\text { Pellet weight }(\mathrm{g})}{\text { Sample weight }(\mathrm{g})} \times 100
$$

\section{Textural Attributes}

Texture analysis was carried out according to the method given by Kumar and Mishra (2003) with slight modifications (Narayana and Gupta, 2013), using a TAXT2i Texture analyser (M/s Stable Micro Systems, UK) fitted with a $25 \mathrm{~kg}$ load cell and was calibrated with a 5 $\mathrm{kg}$ standard dead weight prior to use. For determining the textural attributes, the pasteurized and cooled standardized milk was filled up to $80 \mathrm{ml}$ in the $100 \mathrm{ml}$ pre-sterilized glass beaker and incubation was carried out. Experiments were carried out by compression tests that generated plot of force $(\mathrm{N})$ versus time (s). A $25 \mathrm{~mm}$ perplex cylindrical probe was used to measure texture of yoghurt samples at a temperature of $10 \pm 0.5^{\circ} \mathrm{C}$ performing four repetitions. During analysis the samples were compressed up to $20 \mathrm{~mm}$ of their original depth. The speed of the probe was $0.5 \mathrm{~mm} / \mathrm{s}$ during the compression and $2 \mathrm{~mm} / \mathrm{s}$ during pre-test and relaxation of the samples. From the resulting force-time curves, firmness, i.e., the force for compression, stickiness, i.e., the negative peak force during withdrawal, work of shear and work of adhesion were calculated using the Texture Expert Exceed software (version 2.55) supplied by the manufacturer along with the instrument.

\section{Sensory Evaluation}

On the basis of desirable attributes for good quality yoghurt, the 100 point score card suggested by Ranganadham and Gupta (1987) was used for the sensory evaluation of yoghurt. The values of 100 point score were 
divided for flavour, body \& texture, acidity, colour \& appearance and container and closure viz., 45, 30, 10, 10 and 5, respectively. Overall acceptability score is the collection of the other sensory scores. Yoghurts were sensory evaluated at $10 \pm 1^{\circ} \mathrm{C}$ by a panel of 8 trained judges at National Dairy Research Institute, Karnal.

\section{Statistical Analysis}

Factorial arrangement of treatments in complete randomized design was used. Study was repeated 3 times. SPSS version 16.0 for Windows software (SPSS South Asia (P) Ltd., Bangalore, India) was used to analyse the data. Mean separation was performed by Tukeys' test. Mean \pm SE (Standard Error) was calculated for the compositional data using MS-Excel software (version 2007), wherever required.

\section{Results and Discussion}

Chemical Composition of Optimum Quality Yoghurt

Chemical composition of plain yoghurt made using 1.5 fold UFCL at $2 \%$ IL, which was observed to be optimum, is shown in Table 1.

Table 1 Chemical composition* of optimum quality plain yoghurt made employing UF process

\begin{tabular}{l|c}
\hline \multicolumn{1}{c|}{ Component } & Percentage \\
\hline TS & $13.60 \pm 0.02$ \\
Fat & $3.31 \pm 0.01$ \\
Protein & $5.27 \pm 0.04$ \\
Lactose & $4.20 \pm 0.03$ \\
Ash & $0.82 \pm 0.02$ \\
\hline *Mean \pm SE $(n=3)$
\end{tabular}

*Mean \pm SE $(n=3)$

The best yoghurt is probably made from milk containing 15-16 g/100 g TS and most commercial yoghurts contain 14-15 g/100 g TS (Tamime and Robinson, 1999). Total solids \% of the optimum quality yoghurt obtained in the current experiment was observed to be less compared to the reported values of TS\% of normal market set yoghurt. Therefore, good quality yoghurt can be manufactured with less TS using UF technique without the addition of stabilizers. This could be due to the high protein $\%$ observed in the experimental yoghurt which gives strong gel network giving good body and texture with low whey syneresis. Market plain yoghurt normally contains around $3.5 \%$ protein. Hence, the plain yoghurt made employing UF process is a higher protein product.

Titratable Acidity and pH Profile During Incubation of Yoghurt

Table 2 and 3 shows the changes in TA and $\mathrm{pH}$, respectively, during incubation of plain yoghurt at each UFCL and IL. It was observed that, there was a significant $(\mathrm{P}<0.05)$ interaction effect between UFCL, IL and incubation period (IP) for TA development and $\mathrm{pH}$ reduction of yoghurt. Rate of acidity development and $\mathrm{pH}$ reduction in yoghurt during initial periods of incubation was observed to be slow as expected, followed by a faster acidity development and $\mathrm{pH}$ reduction during the middle of the IP. Again slow rate of acidity development and $\mathrm{pH}$ reduction was observed towards the end of the IP irrespective of the UFCL and the IL used in the yoghurt production (Table 2 and 3). Further, it was observed that, time to reach final desired acidity (i.e. IP) of plain yoghurt decreased with increasing both UFCL and IL. Plain yoghurt prepared with 1 fold UF concentrated milk at $2 \%$ IL took $9 \mathrm{~h}$ to reach desired titratable acidity of $0.8 \% \mathrm{LA}$ (data shown up to $6 \mathrm{~h}$ only), while 1.5 and 2 fold UFCLs took 5.5 and $5.25 \mathrm{~h}$, respectively.

Mistry and Kosikowski (1985) studied the growth of mesophilic lactic cultures in highly concentrated UF cow skim milk retentates $(2.3,2.6,4.3$ and 5.8 UF folds) and observed a higher rate of LA production with increasing UFCL of milk. Earlier studies (Mistry and Kosikowski, 1986; El-Gazzar and Marth, 1991) showed that UF milk is a better growth medium for lactic acid bacteria. In the current study also, it was noted that the acidity development is faster in yoghurt milk which was ultrafiltered. Premaratne and Cousin (1991) studied the $\mathrm{pH}$ reduction due to starter culture growth in UF milk retentates and observed that the $\mathrm{pH}$ of retentates were higher than those of skim milk. This observation can be correlated with the buffering cpacity of UF milk. ElGazzar and Marth (1991) reported that buffering effect of UF milk is mainly due to the retention of proteins and calcium phosphates. Mistry and Kosikowski (1985) catagorized starter cultures as fast, medium and slow depending on the time requred to attain $\mathrm{pH}$ of 4.6 in UF concentrated milk at $32^{\circ} \mathrm{C}$. Further, they reported that fermented products made from UF milk retentate demands more starter culture to produce more LA for the reduction of $\mathrm{pH}$ than necessary for optimal operational levels due to high buffering capacity. However in the current study, 2-3\% IL reduced the $\mathrm{pH}$ of plain yoghurt made using 1.5 fold UFCL, nearly up to 4.6, within 5-5.5 $\mathrm{h}$ without difficulty. Fast $\mathrm{pH}$ reduction was not observed with the yoghurt milk which was not concentrated by ultrafiltration. Further, the reduction of $\mathrm{pH}$ was observed to be proportional to the increase of acidity in ultrafiltered as well as normal yoghurt milk. Some yoghurt culture strains might have capability of reducing $\mathrm{pH}$ of UF retentates faster. Further, ultrafiltration at lower concentration levels as used in this study might have created more favourble nutrient balance for the growth of starter culture used and hence, a faster acidity development and $\mathrm{pH}$ reduction in yoghurt milk. These results could be attributed to variations in the metabolic activities that existed in strains of the same species of microorganisms. However, further studies are needed to confirm the current findings.

Spontaneous Whey Syneresis and WHC of Yoghurts

Whey syneresis is the appearance of whey on the surface of a gel and is a common quality defect of fermented dairy products like yoghurt, which influence the appearance (Abrahamsen and Holmen, 1980; Lucey, 2002). In current study, SWS was not observed in plain yoghurt made using ultrafiltered milk, whereas in the 
yoghurt made from milk which was not subjected to UF, showed significantly $(\mathrm{P}<0.05)$ higher SWS (Table 4). Savello and Dargan (1997) mentioned that the concentration of milk by UF for yoghurt making significantly diminishes susceptibility of yoghurt to whey syneresis. El-Khair (2009) reported that the yoghurts made with added skim milk retentate displayed minimal free whey, whereas the control yoghurt made from added skim milk powder was criticized for whey separation.
Further, they mentioned that, skim milk retentate served as a stabilizer in yoghurts to improve texture and reduce whey separation. During gelation, casein micelles aggregate to form a 3-dimentional network, which, under the microscope looks like a sponge, trapping milk serum and fat (Hassan, 2008). Increase of the density of the protein matrix of yoghurt due to the use of UF concentrated milk, leads to more trapping of milk serum leading to no/less whey syneresis.

Table 2 Titratable acidity*development of yoghurt during incubation at different UFCL and IL

\begin{tabular}{|c|c|c|c|c|c|c|c|c|}
\hline \multirow{2}{*}{ UFCL } & \multirow{2}{*}{$\begin{array}{l}\mathrm{IL} \\
(\%)\end{array}$} & \multicolumn{7}{|c|}{ Incubation period $(\mathrm{h})$} \\
\hline & & 0 & 1 & 2 & 3 & 4 & 5 & 6 \\
\hline \multirow{3}{*}{1} & 2 & $0.16 \pm 0.01^{\mathrm{aA}}$ & $0.18 \pm 0.01^{\mathrm{aB}}$ & $0.22 \pm 0.00^{\mathrm{aC}}$ & $0.33 \pm 0.00^{\mathrm{aD}}$ & $0.42 \pm 0.00^{\mathrm{aE}}$ & $0.49 \pm 0.00^{\mathrm{aF}}$ & $0.54 \pm 0.00^{\mathrm{aG}}$ \\
\hline & 2.5 & $0.16 \pm 0.01^{\mathrm{aA}}$ & $0.18 \pm 0.00^{\mathrm{aB}}$ & $0.22 \pm 0.00^{\mathrm{aC}}$ & $0.35 \pm 0.01^{\mathrm{bD}}$ & $0.45 \pm 0.00^{\mathrm{bE}}$ & $0.52 \pm 0.01^{\mathrm{bF}}$ & $0.57 \pm 0.02^{\mathrm{bG}}$ \\
\hline & 3 & $0.17 \pm 0.01^{\mathrm{aA}}$ & $0.18 \pm 0.00^{\mathrm{aB}}$ & $0.24 \pm 0.01^{\mathrm{bC}}$ & $0.37 \pm 0.00^{\mathrm{cD}}$ & $0.48 \pm 0.00^{\mathrm{cE}}$ & $0.55 \pm 0.02^{\mathrm{cF}}$ & $0.60 \pm 0.00^{\mathrm{cG}}$ \\
\hline \multirow{3}{*}{1.5} & 2 & $0.18 \pm 0.01^{\mathrm{aA}}$ & $0.23 \pm 0.01^{\mathrm{aB}}$ & $0.30 \pm 0.07^{\mathrm{aC}}$ & $0.48 \pm 0.01^{\mathrm{aD}}$ & $0.64 \pm 0.01^{\mathrm{aE}}$ & $0.76 \pm 0.01^{\mathrm{aF}}$ & $0.83 \pm 0.01^{\mathrm{aG}}$ \\
\hline & 2.5 & $0.19 \pm 0.01^{\mathrm{aA}}$ & $0.24 \pm 0.01^{\mathrm{aB}}$ & $0.33 \pm 0.02^{\mathrm{aC}}$ & $0.52 \pm 0.01^{\mathrm{bD}}$ & $0.67 \pm 0.00^{\mathrm{bE}}$ & $0.78 \pm 0.00^{\mathrm{bF}}$ & $0.85 \pm 0.02^{\mathrm{bG}}$ \\
\hline & 3 & $0.19 \pm 0.01^{\mathrm{aA}}$ & $0.25 \pm 0.01^{\mathrm{aB}}$ & $0.35 \pm 0.01^{\mathrm{aC}}$ & $0.58 \pm 0.01^{\mathrm{cD}}$ & $0.72 \pm 0.00^{\mathrm{cE}}$ & $0.80 \pm 0.00^{\mathrm{cF}}$ & $0.87 \pm 0.00^{\mathrm{cG}}$ \\
\hline \multirow{3}{*}{2} & 2 & $0.18 \pm 0.01^{\mathrm{aA}}$ & $0.24 \pm 0.01^{\mathrm{aB}}$ & $0.33 \pm 0.03^{\mathrm{aC}}$ & $0.55 \pm 0.02^{\mathrm{bD}}$ & $0.71 \pm 0.01^{\mathrm{bE}}$ & $0.80 \pm 0.01^{\mathrm{bF}}$ & $0.85 \pm 0.01^{\mathrm{aG}}$ \\
\hline & 2.5 & $0.19 \pm 0.01^{\mathrm{aA}}$ & $0.24 \pm 0.01^{\mathrm{aB}}$ & $0.33 \pm 0.01^{\mathrm{aC}}$ & $0.52 \pm 0.01^{\mathrm{aD}}$ & $0.67 \pm 0.00^{\mathrm{aE}}$ & $0.78 \pm 0.00^{\mathrm{aF}}$ & $0.85 \pm 0.00^{\mathrm{aG}}$ \\
\hline & 3 & $0.19 \pm 0.01^{\mathrm{aA}}$ & $0.25 \pm 0.00^{\mathrm{aB}}$ & $0.35 \pm 0.01^{\mathrm{aC}}$ & $0.58 \pm 0.01^{\mathrm{cD}}$ & $0.72 \pm 0.00^{\mathrm{bE}}$ & $0.80 \pm 0.0^{\mathrm{bF}}$ & $0.87 \pm 0.00^{\mathrm{bG}}$ \\
\hline
\end{tabular}

*mean of 3 trials; ${ }^{\text {abc }}$ mean \pm SD in the same column and UFCL with a different superscript differ significantly $(\mathrm{P}<0.05) ;{ }^{\mathrm{ABCDEFG}} \mathrm{mean} \pm \mathrm{SD}$ in the same row and UFCL with a different superscript differ significantly $(\mathrm{P}<0.05)$

Table $3 \mathrm{pH}^{*}$ reduction of yoghurt during incubation at different UFCL and IL

\begin{tabular}{l|llcccccc}
\hline \multirow{2}{*}{ UFCL } & IL & \multicolumn{7}{c}{ Incubation period (h) } \\
\cline { 2 - 8 } & $(\%)$ & 0 & 1 & 2 & 3 & 4 & 5 & 6 \\
\hline \multirow{3}{*}{1} & 2 & $6.69 \pm 0.01^{\mathrm{bF}}$ & $6.67 \pm 0.01^{\mathrm{aF}}$ & $6.35 \pm 0.01^{\mathrm{bE}}$ & $5.71 \pm 0.01^{\mathrm{cD}}$ & $5.39 \pm 0.01^{\mathrm{cC}}$ & $5.03 \pm 0.03^{\mathrm{cB}}$ & $4.87 \pm 0.02^{\mathrm{cA}}$ \\
& 2.5 & $6.69 \pm 0.01^{\mathrm{abF}}$ & $6.67 \pm 0.01^{\mathrm{aF}}$ & $6.31 \pm 0.03^{\mathrm{bE}}$ & $5.63 \pm 0.01^{\mathrm{bD}}$ & $5.19 \pm 0.07^{\mathrm{bC}}$ & $4.89 \pm 0.01^{\mathrm{bB}}$ & $4.74 \pm 0.01^{\mathrm{aA}}$ \\
& 3 & $6.67 \pm 0.01^{\mathrm{aF}}$ & $6.66 \pm 0.01^{\mathrm{aF}}$ & $6.23 \pm 0.01^{\mathrm{aE}}$ & $5.54 \pm 0.01^{\mathrm{aD}}$ & $5.02 \pm 0.01^{\mathrm{aC}}$ & $4.76 \pm 0.02^{\mathrm{aB}}$ & $4.70 \pm 0.02^{\mathrm{aA}}$ \\
\hline \multirow{3}{*}{1.5} & 2 & $6.70 \pm 0.01^{\mathrm{aE}}$ & $6.27 \pm 0.02^{\mathrm{bD}}$ & $5.87 \pm 0.27^{\mathrm{aC}}$ & $5.08 \pm 0.13^{\mathrm{aB}}$ & $4.81 \pm 0.02^{\mathrm{bAB}}$ & $4.68 \pm 0.01^{\mathrm{bA}}$ & $4.55 \pm 0.01^{\mathrm{bA}}$ \\
& 2.5 & $6.68 \pm 0.03^{\mathrm{aE}}$ & $6.25 \pm 0.01^{\mathrm{bD}}$ & $5.67 \pm 0.01^{\mathrm{aC}}$ & $4.99 \pm 0.30^{\mathrm{aB}}$ & $4.78 \pm 0.01^{\mathrm{abAB}}$ & $4.62 \pm 0.00^{\mathrm{aA}}$ & $4.53 \pm 0.02^{\mathrm{abA}}$ \\
& 3 & $6.67 \pm 0.03^{\mathrm{aF}}$ & $6.20 \pm 0.03^{\mathrm{aE}}$ & $5.60 \pm 0.01^{\mathrm{aD}}$ & $4.77 \pm 0.01^{\mathrm{aC}}$ & $4.74 \pm 0.02^{\mathrm{aC}}$ & $4.60 \pm 0.02^{\mathrm{aB}}$ & $4.51 \pm 0.01^{\mathrm{aA}}$ \\
\hline \multirow{2}{*}{2} & 2 & $6.69 \pm 0.02^{\mathrm{bF}}$ & $6.24 \pm 0.04^{\mathrm{aE}}$ & $5.70 \pm 0.14^{\mathrm{bD}}$ & $5.01 \pm 0.01^{\mathrm{cC}}$ & $4.84 \pm 0.06^{\mathrm{bB}}$ & $4.63 \pm 0.00^{\mathrm{bA}}$ & $4.54 \pm 0.02^{\mathrm{bA}}$ \\
& 2.5 & $6.70 \pm 0.00^{\mathrm{abF}}$ & $6.20 \pm 0.09^{\mathrm{aE}}$ & $5.19 \pm 0.13^{\mathrm{aD}}$ & $4.93 \pm 0.05^{\mathrm{bC}}$ & $4.70 \pm 0.01^{\mathrm{aB}}$ & $4.57 \pm 0.02^{\mathrm{aAB}}$ & $4.48 \pm 0.01^{\mathrm{aA}}$ \\
& 3 & $6.66 \pm 0.01^{\mathrm{aE}}$ & $6.08 \pm 0.15^{\mathrm{aD}}$ & $5.13 \pm 0.01^{\mathrm{aC}}$ & $4.83 \pm 0.02^{\mathrm{aB}}$ & $4.72 \pm 0.00^{\mathrm{aB}}$ & $4.55 \pm 0.03^{\mathrm{aA}}$ & $4.46 \pm 0.01^{\mathrm{aA}}$ \\
\hline
\end{tabular}

*mean of 3 trials; ${ }^{\text {abc }}$ mean \pm SD in the same column and UFCL with a different superscript differ significantly (P<0.05); ${ }^{\mathrm{ABCDEF}}$ mean \pm SD in the same row and UFCL with a different superscript differ significantly $(\mathrm{P}<0.05)$

Table 4 Physical properties* of plain yoghurt as affected by IL and UFCL

\begin{tabular}{l|lcccccc}
\hline \multirow{2}{*}{ IL $(\%)$} & \multirow{2}{*}{ UFCL } & \multicolumn{5}{c}{ Parameter } \\
\cline { 2 - 8 } & & SWS (\%) & WHC (\%) & Firmness (N) & Stickiness (N) & WOS (N.s.) & WOA (N.s.) \\
\hline \multirow{2}{*}{2} & 1 & $1.37 \pm 0.15^{\mathrm{b}}$ & $45.27 \pm 0.27^{\mathrm{a}}$ & $1.35 \pm 0.03^{\mathrm{a}}$ & $-0.38 \pm 0.02^{\mathrm{a}}$ & $40.27 \pm 1.19^{\mathrm{a}}$ & $-2.30 \pm 0.12^{\mathrm{ab}}$ \\
& 1.5 & $0^{\mathrm{a}}$ & $63.49 \pm 1.20^{\mathrm{b}}$ & $1.88 \pm 0.06^{\mathrm{b}}$ & $-0.31 \pm 0.01^{\mathrm{a}}$ & $54.47 \pm 2.32^{\mathrm{b}}$ & $-1.47 \pm 0.15^{\mathrm{b}}$ \\
& 2 & $0^{\mathrm{a}}$ & $68.93 \pm 0.10^{\mathrm{c}}$ & $2.40 \pm 0.17^{\mathrm{c}}$ & $-0.53 \pm 0.16^{\mathrm{a}}$ & $58.55 \pm 2.89^{\mathrm{b}}$ & $-3.60 \pm 1.36^{\mathrm{a}}$ \\
\hline \multirow{3}{*}{2.5} & 1 & $1.33 \pm 0.21^{\mathrm{b}}$ & $45.56 \pm 0.56^{\mathrm{a}}$ & $1.35 \pm 0.07^{\mathrm{a}}$ & $-0.31 \pm 0.07^{\mathrm{b}}$ & $40.87 \pm 3.21^{\mathrm{a}}$ & $-1.94 \pm 0.31^{\mathrm{b}}$ \\
& 1.5 & $0^{\mathrm{a}}$ & $64.15 \pm 0.09^{\mathrm{b}}$ & $1.91 \pm 0.07^{\mathrm{b}}$ & $-0.41 \pm 0.05^{\mathrm{b}}$ & $55.21 \pm 2.85^{\mathrm{b}}$ & $-2.39 \pm 0.52^{\mathrm{ab}}$ \\
& 2 & $0^{\mathrm{a}}$ & $70.00 \pm 0.22^{\mathrm{c}}$ & $2.40 \pm 0.21^{\mathrm{c}}$ & $-0.61 \pm 0.10^{\mathrm{a}}$ & $58.88 \pm 1.76^{\mathrm{b}}$ & $-4.32 \pm 1.46^{\mathrm{a}}$ \\
\hline \multirow{3}{*}{3} & 1 & $1.27 \pm 0.21^{\mathrm{b}}$ & $45.38 \pm 0.40^{\mathrm{a}}$ & $1.33 \pm 0.03^{\mathrm{a}}$ & $-0.37 \pm 0.07^{\mathrm{b}}$ & $39.54 \pm 0.95^{\mathrm{a}}$ & $-1.76 \pm 0.37^{\mathrm{b}}$ \\
& 1.5 & $0^{\mathrm{a}}$ & $66.10 \pm 2.87^{\mathrm{b}}$ & $1.81 \pm 0.10^{\mathrm{b}}$ & $-0.40 \pm 0.09^{\mathrm{ab}}$ & $53.88 \pm 0.53^{\mathrm{b}}$ & $-2.25 \pm 0.72^{\mathrm{ab}}$ \\
& 2 & $0^{\mathrm{a}}$ & $66.90 \pm 2.26^{\mathrm{b}}$ & $2.42 \pm 0.18^{\mathrm{c}}$ & $-0.59 \pm 0.08^{\mathrm{a}}$ & $59.52 \pm 1.91^{\mathrm{c}}$ & $-3.82 \pm 1.04^{\mathrm{a}}$ \\
\hline
\end{tabular}

*Mean of 3 trials; ${ }^{\mathrm{a}, \mathrm{b}, \mathrm{c}}$ mean $\pm \mathrm{SD}$ within each column and $\mathrm{IL}$ with different superscripts differ significantly $(\mathrm{P}<0.05)$ 
According to Lee and Lucey (2004), another factor affecting SWS of yoghurts is the acidification rate. A longer fermentation time allows more structural rearrangements, which leads to formation of weak structure with increased SWS in yoghurts. In the current study also, acidification rate was lowest in plain yoghurt made from milk concentrated to 1 UF fold (without UF) and whey syneresis was observed. Spontaneous whey syneresis of plain yoghurt was not affected by IL. Lee and Lucey (2004) reported that the combined effect of inoculation rate $(0.5-4 \%)$ and incubation temperature (40 and $45.7^{\circ} \mathrm{C}$ ) had a significant effect on whey separation of yoghurts. However, according to the above authors, dominant factor affecting whey separation of yoghurts was incubation temperature and not the inoculation rate.

WHC of plain yoghurt increased significantly $(\mathrm{P}<0.05)$ with increasing UFCL of milk, while, IL did not affect. Significant $(\mathrm{P}<0.05)$ interaction effect was found between UFCL and IL for WHC of plain yoghurts (Table 4). At 2 and $2.5 \%$ IL, WHC of yoghurts increased drastically with increasing UFCL, while, at 3\% IL did not differ in between 1.5 and 2 fold UFCLs. Several studies reported that increasing milk concentration resulted in higher WHC of yoghurt due to increase of the protein matrix density (Harwalkar and Kalab, 1986; Sodini et al., 2004; Doleyres et al., 2005). The WHC of yoghurt made from reconstituted non fat dry milk was proportional to TS content (Harwalkar and Kalab, 1986). The composition of solid-non-fat changes in favour of proteins with UF (Becker and Puhan, 1989), leading to increased WHC of yoghurts. Sodini et al. (2004) reported that effect of inoculation strength has a minor effect on yoghurt texture including WHC.

\section{Textural Attributes of Yoghurts}

Values of textural attributes \{firmness, stickiness, work of shear (WoS) and work of adhesion (WoA) \} of plain yoghurt prepared with milk concentrated to different UFCLs and ILs increased significantly $(\mathrm{P}<0.05)$ with increasing UFCL (Table 4). Firmness (the peak force obtained during the penetration of the probe) of yoghurt at 1.5 fold UFCL, which had an average value of $1.89 \mathrm{~N}$ was observed to be optimum. The textural properties of yoghurt including firmness are affected by TS content of the product and protein- protein interactions (Tamime and Deeth, 1980; Penna et al., 2001; Kristo et al., 2003). Several researches (Becker and Puhan, 1989; Hess et al., 1997; Trachoo and Mistry, 1998) quantified the yoghurt firmness and reported that it could be improved by increasing TS level, especially proteins. None of the textural attributes of plain yoghurts showed significant relation with ILs used which agrees with early reports (Sodini et al., 2004). Further, Rönnegard and Dejmek (1993) showed a lack of effect of inoculation strength (1 to $5 \%$ ) on linear viscoelastic properties of the yoghurt.

\section{Sensory Attributes of Plain Yoghurts}

Sensory evaluation scores for the plain yogurt prepared from 1.5 and 2 fold UF concentrated milk are shown in the Table 5. Yoghurts prepared using 1 fold UF concentrated milk were not up to the mark and hence, could not be given for the sensory panel. Body \& texture and overall acceptability scores were significantly $(\mathrm{P}<0.05)$ better in plain yoghurts made from milk concentrated to 1.5 fold compared to plain yoghurts made from milk concentrated to 2 fold UFCL at all the ILs. Further, it was observed that the flavor score at 2.5 and $3 \%$ IL; acidity score at $3 \%$ IL and colour \& appearance score at $3 \%$ IL were significantly $(\mathrm{P}<0.05)$ better in plain yoghurts made from 1.5 fold UF concentrated milk compared to plain yoghurts made from 2 fold UF concentrated milk.

A too soft yoghurt coagulum is one of the most common consistency defects of set yoghurt. However, too firm coagulum of yoghurt can also be considered as a defect, sometimes referred to as "pudding like" (Abrahamsen and Holmen, 1980). In current study, plain yoghurt made from 2 fold UF concentrated milk was criticized to be too firm. Even though, incubation was stopped nearly at similar acidity level, significantly $(\mathrm{P}<0.05)$ lower acidity scores obtained by plain yoghurts made from milk concentrated to 2 fold UFCL might be due to the buffering effect due mainly to concentration of proteins. This in turn reflected in flavour and overall acceptability scores giving less acceptability to the yoghurts made from 2 fold UF concentrated milk. However, none of the sensory attributes of plain yoghurt differ significantly with ILs studied.

Table 5 Sensory scores of plain yoghurt as affected by IL and UFCL

\begin{tabular}{c|lrcccc}
\hline \multirow{2}{*}{$\begin{array}{c}\text { IL } \\
(\%)\end{array}$} & UFCL & & \multicolumn{5}{c}{ Sensory score } \\
\cline { 3 - 7 } & & Flavour & Body \& texture & Acidity & $\begin{array}{c}\text { Colour \& } \\
\text { appearance }\end{array}$ & $\begin{array}{c}\text { Overall } \\
\text { acceptability }\end{array}$ \\
\hline \multirow{2}{*}{2} & 1.5 & $40.85 \pm 1.67^{\mathrm{a}}$ & $28.15 \pm 1.10^{\mathrm{b}}$ & $8.76 \pm 0.81^{\mathrm{a}}$ & $9.04 \pm 0.66^{\mathrm{a}}$ & $91.80 \pm 3.11^{\mathrm{b}}$ \\
& 2 & $40.13 \pm 1.65^{\mathrm{a}}$ & $25.46 \pm 1.10^{\mathrm{a}}$ & $8.61 \pm 0.73^{\mathrm{a}}$ & $9.06 \pm 0.59^{\mathrm{a}}$ & $88.26 \pm 2.71^{\mathrm{a}}$ \\
\hline \multirow{2}{*}{2.5} & 1.5 & $40.83 \pm 1.44^{\mathrm{b}}$ & $27.72 \pm 1.33^{\mathrm{b}}$ & $8.48 \pm 0.69^{\mathrm{a}}$ & $9.06 \pm 0.68^{\mathrm{a}}$ & $91.09 \pm 2.65^{\mathrm{b}}$ \\
& 2 & $39.28 \pm 2.36^{\mathrm{a}}$ & $25.04 \pm 1.11^{\mathrm{a}}$ & $8.57 \pm 0.47^{\mathrm{a}}$ & $9.06 \pm 0.68^{\mathrm{a}}$ & $86.94 \pm 3.32^{\mathrm{a}}$ \\
\hline \multirow{2}{*}{3} & 1.5 & $41.07 \pm 2.02^{\mathrm{b}}$ & $28.65 \pm 0.94^{\mathrm{b}}$ & $8.78 \pm 0.75^{\mathrm{b}}$ & $9.17 \pm 0.55^{\mathrm{b}}$ & $92.67 \pm 2.89^{\mathrm{b}}$ \\
& 2 & $39.91 \pm 1.45^{\mathrm{a}}$ & $25.35 \pm 1.34^{\mathrm{a}}$ & $8.39 \pm 0.67^{\mathrm{a}}$ & $8.69 \pm 0.71^{\mathrm{a}}$ & $87.33 \pm 2.39^{\mathrm{a}}$ \\
\hline
\end{tabular}

${ }^{\mathrm{a}, \mathrm{b}}$, mean $\pm \mathrm{SD}(n=27)$ within each column and IL with different superscripts differ significantly $(\mathrm{P}<0.05)$ 


\section{Conclusions}

Ultrafiltration concentration level and IL had a significant influence on TA development and $\mathrm{pH}$ reduction during incubation of yoghurt. Yoghurt prepared from 1.5 fold UF concentrated milk standardized to minimum $3.3 \%$ fat gave an optimum quality product with any of the ILs studied. This yoghurt formulation having $5.27 \%$ protein did not affect the fermentation step. Even though, 3\% IL took less time than $2 \%$ IL to attain similar acidity of yoghurt made from 1.5 fold UF concentrated milk, considering the cost of Direct Vat Set cultures, 2\% IL can be recommended either with UF concentrated milk or with milk, which is not concentrated by UF for yoghurt making. Spontaneous whey syneresis of yoghurt could be effectively controlled by applying UF process. Hence, additional stabilizers are not needed to control SWS, which is a common defect in set yoghurt.

\section{Acknowledgement}

The first author acknowledges the Sri Lanka Council for Agricultural Research Policy for scholarship awarded to carry out this research.

\section{References}

Abrahamsen RK, Holmen TB. 1980. Yoghurt from hyperfiltrated, ultrafiltrated and evaporated milk and from milk with added milk powder. Milchwissenschaft, 35: 399-402.

Amatayakul T, Halmos AL, Sherkat F, Shah NP. 2006. Physical characteristics of set yoghurt made with altered casein to whey protein ratios and EPS-producing starter cultures at 9 and $14 \%$ total solids. Food Hydrocoll, 20: 314-324.doi: http://dx.doi.org/10.1016/j.foodhyd.2005.02.015

Anonymous. 2005. Manual of methods of analysis of foods (milk and milk products). Directorate general of health services, Ministry of health and family welfare, Government of India, New Delhi. 36-37.

Anonymous. 2014. Global Yoghurt Market 2014-2018, available at: http://www.technavio. com/ report/global-yogurt-market 20142018.

Becker T, Puhan Z. 1989. Effect of different processes to increase the milk solids non-fat content on the rheological properties of yoghurt. Milchwissenschaft, 44: 626-629.

Anonymous. 1977. Determination of fat by ther Gerber method Milk products. IS: 1224 (part II) - 1977. Bureau of Indian Standards, Manak Bhavan, New Delhi.

Anonymous. 1981a. Rapid examination of milk. In: Handbook of Food Analysis (SP: 18 - Part XI): Dairy Products. Bureau of Indian Standards, Manak Bhavan, New Delhi. 5-20.

Anonymous. 1981b. Chemical examination of milk. In: Handbook of Food Analysis (SP: 18 - Part XI): Dairy Products. Bureau of Indian Standards, Manak Bhavan, New Delhi. 21-44.

Doleyres Y, Schaub L, Lacroix C. 2005. Comparison of the functionality of exopolysaccharides produced in situ or added as bio ingredients on yogurt properties. J Dairy Sci, 88: 41464156.doi: http://dx.doi.org/10.3168/jds.S0022-0302(05)73100-3

El-Gazzar FE, Marth EH. 1991. Ultrafiltration and reverse osmosis in dairy technology: a review. J Food Protect, 54: 801-809.

El-Khair AAA. 2009. Production and evaluation of a high protein version of non-fat yoghurt. Res J Agr Biol Sci, 5: 310-316.

Harwalkar VR, Kalab M. 1986. Relationship between microstructure and susceptibility to syneresis in yoghurt made from reconstituted nonfat dry milk. Food Microstruct, 5: 287294.
Hassan AN. 2008. ADSA Foundation Scholar Award: Possibilities and challenges of exopolysaccharide-producing lactic cultures in dairy foods. J Dairy Sci, 91: 1282-1298.doi: http://dx.doi.org/10.3168/jds.2007-0558

Hess SJ, Roberts RF, Ziegler GR. 1997. Rheological properties of nonfat yogurt stabilized using Lactobacillus delbrueckii ssp. bulgaricus producing exopolysaccharide or using commercial stabilizer systems. J Dairy Sci, 80: 252-263.doi: http://dx.doi.org/10.3168/jds.S0022-0302(97)75933-2

Horiuchi H, Inoue N, Liu E, Fukui M, Sasaki Y, Sasaki T. 2009. A method for manufacturing superior set yogurt under reduced oxygen conditions. J Dairy Sci, 92: 4112-4121.doi: http://dx.doi.org/10.3168/jds.2008-1747

Kristo E, Biliaderis CG, Tzanetakis N. 2003. Modelling of the acidification process and rheological properties of milk fermented with a yogurt starter culture using response surface methodology. Food Chem, 83: 437-446.doi: http://dx.doi.org/10.1016/S0308-8146(03)00126-2

Kumar P, Mishra HN. 2003. Effect of mango pulp and soy milk fortification on the texture profile of set yoghurt made from buffalo milk. J Text Stud, 34: 249-269.doi: http://dx.doi.org/10.1111/j.1745-4603.2003.tb01060.x

Lee WJ, Lucey JA. 2004. Structure and physical properties of yogurt gels: Effect of inoculation rate and incubation temperature. J Dairy Sci, 87: 3153-3164.doi: http://dx.doi.org/10.3168/jds.S0022-0302(04)73450-5

Lucey JA. 2001. The relationship between rheological parameters and whey separation in milk gels. Food Hydrocoll, 15: 603608.doi: http://dx.doi.org/10.1016/S0268-005X(01)00043-1

Lucey JA. 2002. Formation and physical properties of milk protein gels. J Dairy Sci, 85: 281-294.doi: http://dx.doi.org/10.3168/jds.S0022-0302(02)74078-2

Mahdian E, Tehrani MM. 2007. Evaluation the Effect of Milk Total Solids on the Relationship Between Growth and Activity of Starter Cultures and Quality of Concentrated Yoghurt. American-Eurasian J Agri Env Sci, 2: 587-592.

Menefee SG, Overman OR. 1940. Semi-micro Kjeldhal method for determination of total nitrogen in milk. J Dairy Sci, 23: 11771185.doi: http://dx.doi.org/10.3168/jds.S0022-0302(40)92829-6

Mistry VV, Kosikowski FV. 1985. Growth of Lactic acid bacteria in highly concentrated ultrafiltered skim milk retentates. J Dairy Sci, 68: 536-2543.doi: http://dx.doi.org/10.3168/jds.S00220302(85)81134-6

Mistry VV, Kosikowski FV. 1986. A naturally buffered bulk retentate starter from ultrafiltered milk. J Dairy Sci, 69: 945950.doi: http://dx.doi.org/10.3168/jds.S0022-0302(86)80485-4

Modler H, Larmond M, Lin C, Froelich D, Emmons DB. 1983. Physical and sensory properties of yogurt stabilized with milk proteins. J Dairy Sci, 66: 422-429.doi: http://dx.doi.org/10.3168/jds.S0022-0302(83)81809-8

Narayana NMNK, Gupta VK. 2013. Effect of total milk solid content adjusted by adding ultrafiltered milk retentate on quality of set mango yoghurt. Int J Dairy Tech, 66: 570-575.doi: http://dx.doi.org/10.1111/1471-0307.12081

Penna ALB, Sivieri K, Oliveira MN. 2001. Relation between quality and rheological properties of lactic beverages. J Food Eng, 49: 7-13.doi: http://dx.doi.org/10.1016/S0260-8774(00)00179-5

Premaratne AJ, Cousin MA. 1991. Microbiological analysis and starter culture growth in retentates. J Dairy Sci, 74: 32843292.doi: http://dx.doi.org/10.3168/jds.S0022-0302(91)78514-7

Ranganadhan M, Gupta SK. 1987. Sensory evaluation of dahi and yoghurt. Indian Dairyman, 39: 493-497.

Rönnegard E, Dejmek P. 1993. Development and breakdown of structure in yogurt studied by oscillatory rheological measurements. Lait, 73: 371-379.

Salaun F, Mietton B, Gaucheron F. 2005. Review-Buffering capacity of dairy products. Int Dairy J, 15: 95-109.

Savello PA, Dargan RA. 1997. Reduced yoghurt syneresis using ultrafiltration and very high temperature heating. Milchwisscenschaft, 52: 573-577. 
Sodini I, Remeuf F, Haddad S, Corrieu G. 2004. The relative effect of milk base, starter and process on yoghurt texture: A review. Crit Rev Food Sci, 44: 113-137.doi: http://dx.doi.org/10.1080/10408690490424793

Supavititpatana P, Wirjantoro T, Raviyan P. 2009. Effect of sodium caseinate and whey protein isolate fortification on the physical properties and microstructure of corn milk yoghurt. CMU J Nat Sci, 8: 247-263.
Tamime AY, Deeth HC. 1980. Yoghurt: technology and biochemistry. J Food Prot, 43: 939-977.

Tamime AY, Robinson RK. 1999. Yoghurt: Science and Technology, $2^{\text {nd }}$ Edtn. Cambridge Woodhead Publishing Ltd.

Trachoo N, Mistry VV. 1998. Application of ultrafiltered sweet buttermilk and sweet buttermilk powder in the manufacture of nonfat and low fat yogurts. J Dairy Sci, 81: 3163-3171.doi: http://dx.doi.org/10.3168/jds.S0022-0302(98)75882-5 